\title{
Acute Tissue Trauma as a Trigger for Gynecomastia Development and Progression
}

\section{Yordan P Yordanov ${ }^{1^{*}}$ and Aylin Shef ${ }^{2}$}

1 Unit of Plastic Reconstructive and Aesthetic Surgery, MHAT "Uni Hospital", Panagyurishte, Bulgaria

${ }^{2}$ Department of Dermatology, Military Medical Academy, Sofia, Bulgaria

"Corresponding author: Yordan P. Yordanov, Unit of Plastic Reconstructive and Aesthetic Surgery, MHAT "Uni Hospital”, Panagyurishte, Bulgaria, Tel: +35935788581; E-mail: yordanov_vma@abv.bg

Rec date: October 22, 2017; Acc date: December 18, 2017; Pub date: December 20, 2017

Copyright: (c) 2017 Yordanov YP, et al. This is an open-access article distributed under the terms of the creative commons attribution license, which permits unrestricted use, distribution, and reproduction in any medium, provided the original author and source are credited.

\begin{abstract}
Over the last 50 years a great variety of etiologic factors for gynecomastia have been investigated and discussed. However, the possible role of the chronic and acute tissue trauma still remains unclear. The authors report on and discussed the possible role of a single episode of acute trauma as a trigger mechanism for the onset of breast enlargement.
\end{abstract}

Keywords: Gynecomastia; Asymmetrical; Trauma; Secondary progression

\section{Introduction}

Gynecomastia is characterized by a benign enlargement of the male breast due to proliferation of the glandular tissue [1-3] which has many identifiable causes (Table 1). Although a few studies have discussed the possible role of the chronic tissue trauma [4-7], to the date no report has explained the role of the acute trauma as a trigger for development or evolution of preexisting gynaecomastia.

We have operated on a patient with unilateral breast enlargement of preexisting stable gynecomastia after a single episode of ipsilateral acute trauma.

\section{Case Report}

A 34-year-old fighter had been hit with knuckle-duster in the left breast thirteen months ago. Four weeks afterwards a unilateral breast enlargement on the traumatized side appeared and started progressing over time. The clinical history revealed a previously existing mild symmetrical bilateral gynecomastia presented since the puberty with no familial history or medication use including anabolic steroids.

On physical examination, an asymmetrical non-painful gynecomastia was found. Pectoralis muscle examination revealed no signs of asymmetry. Endocrine status tests showed normal hormonal values. Mammography demonstrated asymmetrical but homogeneous breast fibrofatty tissue depositions with no calcifications on both sides.

The patient underwent a minimally invasive bilateral breast reduction [8]. The breast tissue specimens (Figure 1) were histologically studied. Surgical recovery was uneventful and at nine months a symmetrical appearance and a satisfactory for the patient outcome was registered.

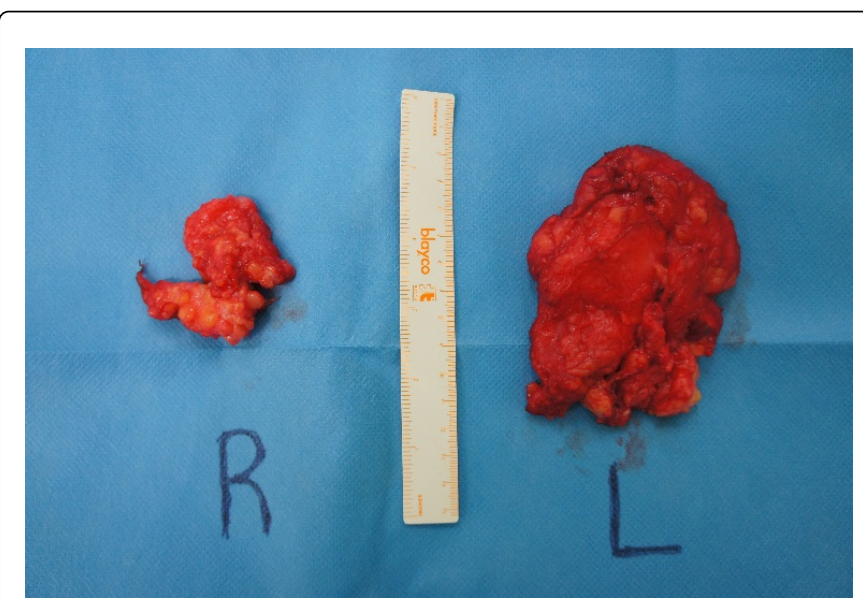

Figure 1: Dissected specimens of the two breasts. Significant difference in the amount of the removed tissue is observed.

\section{Discussion}

Common causes for male breast enlargement include hormonal aberrations, carcinoma, endocrine disease, systemic disorders, and certain drugs [3]. Obesity can be associated with increased peripheral conversion of androgens to estrogens and is often associated with a higher prevalence of gynecomastia [5]. However, our patient was nonobese- BMI $25.06 \mathrm{~kg} / \mathrm{m} 2$. From the other hand, we observed a significant macroscopic difference in the amount of tissue which was removed from both sides (Figure 1).

Our clinical observations correlated with the histological findings showing no significant fat deposition and obvious differences between the two samples: florid pattern changes in the left breast (the traumatized one) and fibrous pattern changes in the right breast which was a sign of an active process of proliferation on the left side. 
Citation: Yordanov YP, Shef A (2017) Acute Tissue Trauma as a Trigger for Gynecomastia Development and Progression. J Trauma Treat 6: 409. doi:10.4172/2167-1222.1000409

Page 2 of 3

\begin{tabular}{|c|c|}
\hline \multicolumn{2}{|r|}{ Causes of Gynecomastia } \\
\hline \multirow{3}{*}{ Developmental/Physiologic } & Neonatal \\
\hline & Pubertal \\
\hline & Aging \\
\hline \multicolumn{2}{|r|}{ Drug-induced } \\
\hline \multicolumn{2}{|c|}{ Hypogonadism (decreased androgen synthesis or increased androgen resistance) } \\
\hline \multirow{2}{*}{ Primary } & Acquired (trauma, infection, torsion, radiation exposure, mumps, chemotherapy) \\
\hline & Congenital \\
\hline \multirow{3}{*}{ Secondary } & Hypogonadotropic hypogonadism \\
\hline & Kallmann syndrome \\
\hline & Pituitary failure (infarction, infection, neoplasm) \\
\hline \multirow{4}{*}{ Tumors (increased estrogen production) } & Steroid-producing (adrenal, testis) \\
\hline & Human chorionic gonadotropin-producing (testis and others) \\
\hline & Aromatase-producing (testis) \\
\hline & Bronchogenic carcinoma \\
\hline \multirow{4}{*}{ Systemic } & Thyrotoxicosis (altered testosterone/estrogen binding) \\
\hline & Renal failure (acquired testicular failure) \\
\hline & Cirrhosis (increased substrate for peripheral aromatization) \\
\hline & Adrenal (adrenocorticotropic hormone deficiency or congenital adrenal hyperplasia) \\
\hline \multirow{6}{*}{ Congenital disorders } & Klinefelter syndrome \\
\hline & Enzyme defects of testosterone synthesis (may be late onset) \\
\hline & Vanishing testis syndrome (anorchia) \\
\hline & Androgen resistance syndromes \\
\hline & True hermaphroditism and related conditions \\
\hline & Increased peripheral tissue aromatase \\
\hline \multicolumn{2}{|r|}{ Familial } \\
\hline \multirow{9}{*}{ Miscellaneous } & HIV \\
\hline & Chest wall trauma \\
\hline & Psychological stress \\
\hline & Spinal cord injury \\
\hline & Malnutrition / refeeding (increased substrate for peripheral aromatization) \\
\hline & Herpes zoster infection \\
\hline & Cystic fibrosis \\
\hline & Alcoholism \\
\hline & Myotonic dystrophy \\
\hline & Idiopathic \\
\hline
\end{tabular}

Table 1: Etiology of gynecomastia. 
Citation: Yordanov YP, Shef A (2017) Acute Tissue Trauma as a Trigger for Gynecomastia Development and Progression. J Trauma Treat 6: 409. doi: $10.4172 / 2167-1222.1000409$

Page 3 of 3

Presentation of unilateral breast enlargement or onset of asymmetrical changes requires exclusion of breast neoplasm which had been done. We even assumed that the asymmetrical enlargement of the left breast can be a result of a resorbed hematoma with fibrosis, but the histological study revealed a paucity of fibrotic changes bilaterally. Furthermore, more fibrosis was found in the right breast- the one with stable gynecomastia.

The clinical case presented in this short commentary article was solved by well-known surgical approach $[8,9]$ but the exact etiology of the new onset of previously existing stable gynecomastia remains unclear to us. However, we are convinced that the pathophysiology was related to the trauma he suffered. We were unable to find any records on the exact relation between the acute trauma and the onset and/or the progression of gynaecomastia. An interesting hypothesis is the one of Kang et al. [5] who assumed that pressure could cause a local release of growth factors that are supposed to trigger differentiation of precursor cells to new mature glandular proliferation, and in turn, causing the development of gynecomastia. It is our conviction that this mechanism could be similar in an acute trauma cases like in our patient.

\section{Conclusion}

The single episode of blunt traumatic injury to the breast could play a main role for progression of preexisting gynecomastia. It is also possible to be a trigger of a "de novo" development of this condition.

\section{References}

1. Lista F, Ahmad J (2011) Gynecomastia. In: Spear SL, Willey SC, Robb GL et al. (eds.) Surgery of the breast: principles and art. (3rd edn). Lippincott Williams \& Wilkins; Philadelphia, USA. pp. 1205-1210.

2. Braunstein GD (2007) Clinical practice. Gynecomastia. N Engl J Med 357: 1229-1237.

3. Rohrich RJ, Ha RY, Kenkel JM, Adams WP Jr (2003) Classification and management of gynecomastia: Defining the role of ultrasound-assisted liposuction. Plast Reconstr Surg 111: 909-923.

4. Arnon O, Barnea Y, Zaretski A, Miller E, Leshem D, et al. (2005) Occupational pseudogynecomastia: A new etiology for unilateral gynecomastia. Plast Reconstr Surg 115: 1e-4e.

5. Kang SG, Song WJ, Kim CH, Kim JW, Tark MS (2012) Unilateral gynecomastia in a tennis player. Arch Plast Surg 39: 675-678.

6. Erol S, Orhan E, Sevin A, Erdoğan B (2010) Trauma: A new pseudogynecomastia cause. Aesthetic Plast Surg 34: 404-405.

7. Greene WW, Howard NJ (1953) Relation of trauma to lesions of the male breast. Am J Surg 85: 431-437.

8. Yordanov Y, Lasso JM, Shef A (2015) Combined surgical treatment of gynecomastia. Acta Medica Bulgarica 42: 43-48.

9. Babigian A, Silverman RT (2001) Management of gynecomastia due to use of anabolic steroids in bodybuilders. Plast Reconstr Surg 107: $240-242$. 